BULLETIN OF POLTAVA
STATE AGRARIAI
ACADEMIV

CONTROL OF ZOOPHILIC FLIES' ATTACKING DAIRY COWS IN LIVESTOCK PREMISES

A. M. Shevchenko, ORCID ID: 0000-0002-9617-3349, E-mail: anshevch74@gmail.com, Sumy National Agrarian University, 160, G. Kondratieva str., 40021 Sumy, Ukraine

Parasitic insects are a significant problem for dairy farming in Ukraine as well as all over the world. Losses of livestock from midges in some countries can reach several million dollars. Treatment of animals with insecticides, among which the group of synthetic pyrethroids should be separately distinguished, is considered to be the most effective way to protect against midges The aim of the paper was to study insecticidalrepellent efficacy of "Ectosan-plus ${ }^{m u ” ~(L L C ~ " B r o v a f a r m a ") ~ i n ~ d i f f e r e n t ~ d i l u t i o n s ~ a g a i n s t ~ z o o p h i l i c ~ f l i e s . ~}$ "Ectosan-plus "mu" consists of two synergistic active ingredients: alfametryn (7.5 \%) and piperonil-butoxide (10.5\%), and a mixture of essential oils of lemon and rose (10\%). "Ectosan-plus"m" is a transparent oily liquid of yellowish color with a mild pleasant specific odor. The parasitological research on testing the impact of insecticide "Ectosan-plus"m" in dilutions of 1:1000 and 1:750 on flying insects was conducted on three groups of cows. At first, the increased activity of the stable fly, Stomoxys calcitrans, was established on the experimental farm under the following weather conditions: the average daytime air temperature was $+19-21{ }^{\circ} \mathrm{C}$, the nighttime one $-+8-12{ }^{\circ} \mathrm{C}$. It was proved that the water solution (1:750) of "Ectosanplus $^{m n}$ " should be used once every two days for the effective protection of dairy cows against the stable flies' attack in the farm premises. The insect repellent effectiveness (IRE) of the spray material is more than $80 \%$. The rate of the preparation consumption is $250 \mathrm{~cm}^{3}$ per animal. Repeated treatment of animals with the solution increases the insecticidal activity of the preparation up to three days, which indicates its probable cumulative effect. In case of a moderate or low intensity of the zoophilic flies' attack on cows, the sufficient treatment is once every three days; in case of high intensity - every two days. The water solution of "Ectosan-plus ${ }^{m u " ~ i n ~ t h e ~ d i l u t i o n ~ o f ~ 1: 1000 ~ d o e s ~ n o t ~ p r o v i d e ~ s u f f i c i e n t ~ p r o t e c t i o n ~ o f ~ c o w s ~ d u r i n g ~ d a y l i g h t ~}$ time as the SF reduces to 69,0\% in 6 hours after the treatment. Throughout all the experiment period, no external signs of intoxication were detected in the test animals.

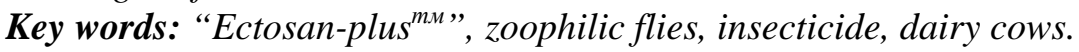

\title{
ЩОДО КОНТРОЛЮ НАПАДУ ЗООФІЛЬНИХ МУХ НА КОРІВ В УМОВАХ ТВАРИННИЦЬКИХ ПРИМІЩЕНЬ
}

\section{А. М. Шевченко,}

Сумський національний аграрний університет, вул. Герасима Кіндратієва, 160, м. Суми, 40021, Україна

Паразитичні комахи є значною проблемою для молочного скотарства в Україні та світі. Найбільш ефективним способом захисту від гнусу вважається обробка тварин інсектицидами, з-поміж яких окремо необхідно виділити групу синтетичних піретроїдів. Метою роботи було вивчити інсектицидно-репелентну ефективність препарату «Ектосан-плюс ${ }^{m м}$ 》 (ТОВ «Бровафарма») в різному розведенні проти зоофільних мух. «Ектосан-плюс ${ }^{m м}$ » складається з двох синергічних діючих речовин: альфаметрину (7,5\%) і піпероніл-бутоксиду (10,5\%), а також суміші ефірних олій лимона і троянди (10\%). Паразитологічні дослідження щодо тестування впливу на літаючих комах інсектициду «Ектосан-плюс ${ }^{\text {м } у ~ у ~ р о з в е д е н н і ~ 1: 1000 ~ і ~ 1: 750 ~ б у л и ~ п р о в е д е н і ~ н а ~ т р ь о х ~ г р у п а х ~ к о р і в . ~ П о п е р е д н ь о ~ в ~ д о с л і д-~}$ ному господарстві була встановлена підвищена активність Stomохуs calcitrans за таких погодних умов: денна середньодобова температура повітря $+19-21{ }^{\circ} \mathrm{C}$, нічна $-+9-12{ }^{\circ} \mathrm{C}$. Доведено, що у приміщеннях ферми для надійного захисту дійних корів від нападу мух-жигалок необхідно використову- 


\section{ВЕТЕРИНАРНА МЕДИЦИНА}

вати водний розчин (1:750) засобу «Ектосан-плюс ${ }^{m м} 》$ один раз на дві доби. Коефічієнт відлякувальної дії (КВД) робочого розчину становить вище $80 \%$. Норма витрати препарату - $250 \mathrm{~cm}^{3}$ на тварину. Повторнаа обробка тварин зазначеним розчином збільшує тривалість інсектицидної дії препарату до трьох діб, ще вказує на ймовірну накопичувальну дію засобу. У разі помірної чи низької інтенсивності нападу зоофільних мух на корів достатньо однієї обробки раз на три доби; за високої інтенсивності - раз на дві доби. «Ектосан-плюс ${ }^{m м} »$ у розведенні водою 1:1000 не забезпечує достатній захист корів протягом світлового часу доби, оскільки КВД через 6 годин після обробки знижується до 69,0 \%. Упродовж всього періоду експерименту зовнішніх проявів інтоксикаиії не було зафіксовано у жодної з дослідних тварин.

Ключові слова: «Ектосан-плюс ${ }^{m м}$, зоофільні мухи, інсектицид, дійні корови.

\section{ОТНОСИТЕЛЬНО КОНТРОЛЯ НАПАДЕНИЙ ЗООФИЛЬНЫХ МУХ НА КОРОВ В УСЛОВИЯХ ЖИВОТНОВОДЧЕСКИХ ПОМЕЩЕНИЙ}

\section{А. Н. Шевченко,}

Сумской национальный аграрный университет, ул. Г. Кондратьева, 160, г. Сумы, 40021, Украина

Паразитические насекомые являются значительной проблемой для молочного скотоводства в Украине. Наиболее эффективным способом защиты от гнуса считается обработка животных инсектицидами. Целью работы было изучить инсектицидно-репеллентную эффективность препарата «Эктосан-плюс "м» в разном разведении против зоофильных мух. Доказано, что для надежной защиты дойных коров от нападения Stomoхуs calcitrans необходимо использовать водный раствор (1:750) «Эктосан-плюс ${ }^{m м » ~ о д и н ~ р а з ~ в ~ д в о е ~ с у т о к . ~ К о э ф ф и ч и е н т ~ о т п у г и в а ю щ е г о ~ д е и ̆ с т в и я ~ р а б о ч е г о ~}$ раствора составляет выше $75 \%$. Норма расхода препарата - $250 \mathrm{cм}^{3}$ на жсивотное.

Ключевые слова: «Эктосан-плюс ${ }^{m м}$ 》, зоофильные мухи, инсектицид, дойные коровы.

\section{Вступ}

Молочне скотарство у структурі аграрного сектору економіки України традиційно займає одне 3 провідних місць [1]. Однак, за даними Продовольчої та сільськогосподарської організації ООН (FAO), навіть у розвинених країнах Свропи втрати від різних захворювань худоби складають 10-20\% вартості продукції тваринництва. Для країн з перехідною економікою цей показник досягає 30-40\% [4]. Певну частку збитків спричиняють паразитарні захворювання, зокрема й ентомози [10]. Конкретно від ектопаразитозів за даними FAO/BO3 щорічний збиток у світовому масштабі сягає 7 млрд дол. США, а у США галузь скотарства недоотримує до 608 млн дол. США прибутку [20].

Незважаючи на значну поширеність представників паразитичної ентомофауни, науковці досі не розробили єдиної глобальної стратегії боротьби з ними. Для протидії небезпечним комахам розроблені механічні, фізичні, хімічні, біологічні методи, а також стерилізація членистоногих. Утім більшою мірою повністю ліквідувати гнус у проблемних регіонах неможливо, але це потрібно постійно контролювати на місцевому рівні [19].

Зрозуміло, що застосування простих заходів боротьби з гнусом і зоофільними мухами (закупорка вікон, обробка територій ферм інсектицидами, поліпшення санітарної культури працівників) не забезпечує 100 \% захисту тварин. Використання різних мухоловок і випромінюючих установок малоефективне за умови великої чисельності мух [17]. Найкраще використовувати методи безпосереднього захисту худоби від ектопаразитів за допомогою обробки волосяного покриву тварин інсектицидами й репелентами $[9,16]$.

Тривалий час в Україні та всьому світі основними засобами боротьби з ектопаразитами були препарати на основі фенолу, сірки і гексахлорану. Однак вони не забезпечували стійкого одужання хворих тварин, а сполуки гексахлоранового ряду відзначалися високою токсичністю. Новою ерою в боротьбі зі шкідливими комахами стало відкриття піретроїдів (Pyrethroid - PR). Так, PR 1-го покоління - ефіри хризантемової кислоти (алетрин, фуретрин, циклетрин) - фотонестабільні, але й досі мають обмежене застосування. 1960-1970 pp. після синтезу PR 2-го покоління (перметрину, дельтаметрину та циперметрину) стало можливим замінити екологічно шкідливі хлорорганічні сполуки. У подальшому були синтезовані малотоксичні PR 3-го покоління (цигалотрин, цифлутрин), які в 2,5 рази активніші за дельтаметрин [7].

Синтетичні PR - аналоги природних піретринів, які містяться в багатьох рослинах. Це контактні 


\section{ВЕТЕРИНАРНА МЕДИЦИНА}

або кишкові нейрогенні токсиканти, що не мають системної дії. PR деполяризують мембрани нейронів і нервових закінчень у комах, спричиняють підвищену активність та порушення координації рухів членистоногих з подальшим паралічем кінцівок і дихального центру $[7,11]$.

Дотепер із групи синтетичних PR часто застосовують:

- перметрин («Пірвол», «Креопір»; «Стомазан» і «Анометрин-Н») [6, 12];

- циперметрин («Цимбуш», «Парасект», «Ектопор», «Ектомін» та інші);

- дельтаметрин («Бутокс», «Дельтокс» «К-отрин») [15];

- тетраметрин (лідер цієї групи «Неостомазан»);

- цифлутрин («Байофлай пур-он», «Цифлур») [3].

Можна стверджувати, що промислове виробництво протипаразитарних препаратів, започатковане у XX ст., дало змогу підвищити ефективність терапії інвазійних хвороб тварин і розпочати масштабні заходи з викорінення багатьох із них $[2,8]$. Водночас інсектициди кожного покоління мають певні недоліки: забруднення довкілля, низьку ефективність, токсичність, дорожнечу. Зокрема застосування інсектицидів на конкретних географічних територіях часто потребує пошуку нових профільних препаратів, основними вимогами до яких є виробництво їх згідно зі стандартами GMP, широкий спектр протипаразитарної дії, низька токсичність та екологічна безпечність [13].

Водночас існує загальна теорія залежності інсектоакарицидної активності від структури хімічної сполуки. Нині дослідники здебільшого відходять від спроб варіювання органічних радикалів, зосереджуючись на розробках альтернативних методів синтеза відомих і апробованих сполук або підборі вдалої композиції стереоізомерів (як у випадку із синтезом PR) [14]. Саме тоді терапевтична дія лікарських речовин залежать не лише від хімічної структури препаратів, але й від фізичного стану, консистенції, природи і якості допоміжних речовин, лікарської форми, технології виготовлення тощо [17]. Одним із перспективних напрямів роботи фарміндустрії $є$ підбір допоміжних речовин або нейтральної основи для лікарських препаратів, яка повинна сприяти синергізму компонентів і гальмувати прояв небажаних властивостей, забезпечувати потрібну форму та консистенцію препарату. 3 цією метою застосовують силікати, поверхнево-активні речовини або рідини [6, 8]. Саме тому виникає нагальна потреба створення та всебічного вивчення дії нових (за діючими речовинами) інсектицидів.

У зв'язку з вищенаведеним метою роботи було з'ясувати інсектицидно-репелентну ефективність препарату «Ектосан-плюс ${ }^{\mathrm{TM}} »$ у різних розведеннях відносно зоофільних мух.

\section{Матеріали іметоди досліджень}

Дослідження проводили в умовах тваринницьких приміщень ПСП «Волинь» Рівненського району Рівненської області на трьох групах корів: двох дослідних $(\mathrm{n}=7)$ та контрольній $(\mathrm{n}=6)$. Тварини, відібрані за принципом аналогів, протягом всього експерименту залишались у приміщенні.

Для обробок корів використовували препарат «Ектосан-плюс ${ }^{\mathrm{TM}} »$ виробництва ТОВ «Бровафарма» (Україна).

«Ектосан-плюс ${ }^{\mathrm{TM}} »-$ це композитний препарат з двох синергічних діючих речовин (ДР): альфаметрину $(7,5 \%)$ і піпероніл-бутоксиду (10,5\%), а також суміші ефірних олій лимона і троянди (10 \%) у носієві з органічних розчинників. Препарат має форму прозорої маслянистої рідини світло-жовтого кольору з легким приємним специфічним запахом.

Корови обох дослідних груп оброблялися робочими розчинами інсектициду о 9 годині вранці після доїння.

Для тварин першої групи було застосовано розведення «Ектосан-плюс ${ }^{\mathrm{TM}} »$ водою $-1: 1000$, для другої - 1:750. Норма витрати розчинів становила $250 \mathrm{~cm}^{3}$ на тварину. Корів другої дослідної групи на третю добу експерименту обробляли інсектицидом повторно.

Тварини контрольної групи залишалися необробленими (інтактні корови).

Ентомологічну ефективність препарату «Ектосан-плюс ${ }^{\mathrm{TM}} »$ визначали за допомогою обрахунку коефіцієнта відлякувальної дії (КВД) за формулою [5]:

$$
\text { КВД }=100-\frac{\mathrm{A} \times \mathrm{B}_{1}}{\mathrm{~B} \times \mathrm{A}_{1}} \times 100,
$$

де А i В - число комах відповідно на обробленій і контрольній тваринах у період досліду; $\mathrm{A}_{1}$ i $\mathrm{B}_{1}-$ те ж до досліду.

Статистичну обробку одержаного масиву даних проводили шляхом визначення середнього арифметичного (M), його похибки (m) та рівня вірогідності (p) з використанням таблиці t-критеріїв Ст’юдента. 


\section{ВЕТЕРИНАРНА МЕДИЦИНА}

Результати досліджень та їх обговорення

На території дослідного господарства в осінній період були проведені щоденні спостереження за динамікою активності зоофільних мух. 3-поміж виявлених комах $90 \%$ складали мухи-жигалки (Stomoxys calcitrans Linnaeus, 1758), які активно нападали на тварин в умовах приміщень.

Важливу роль у масовій активності мух відігравали сприятливі погодні умови. Підвищена чисельність мух у господарстві спостерігалась у вересні: за денної середньодобової температури повітря $+19-21^{\circ} \mathrm{C}$ та нічної $-+10-12^{\circ} \mathrm{C}$. Сезонне поширення зоофільних мух відбувалось, незважаючи на задовільний стан санітарної культури на території ферми. На початку досліду перед обробкою корів

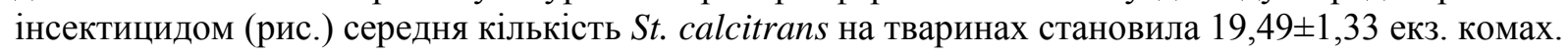

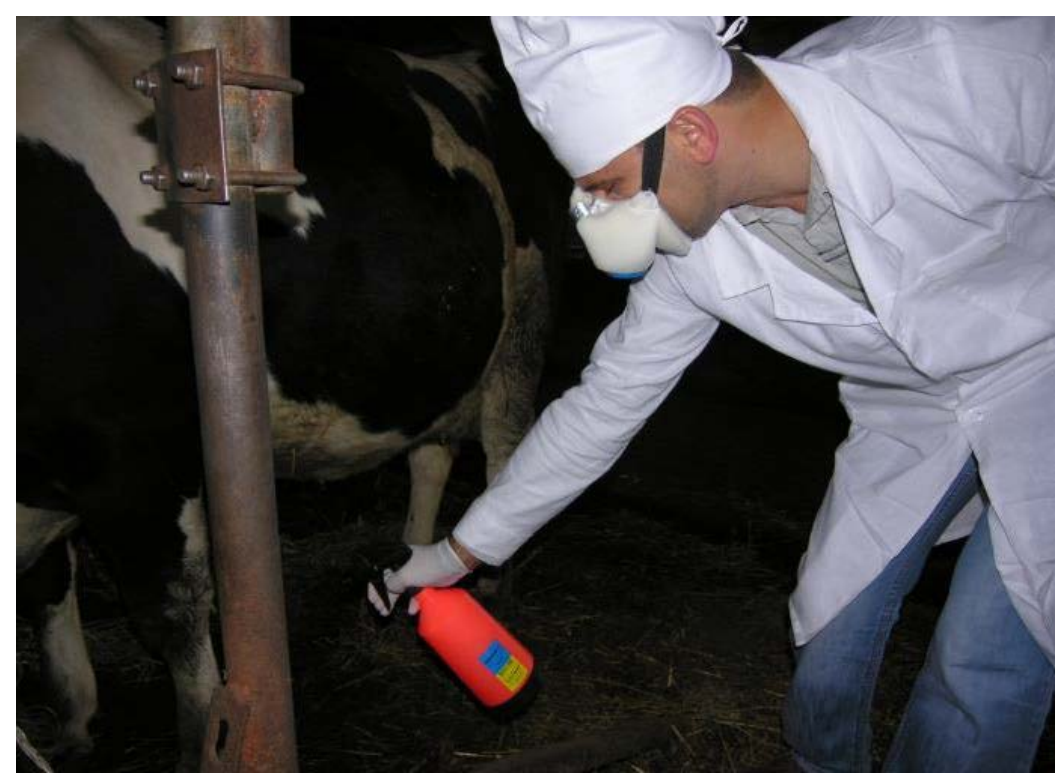

Рис. Обробка тварин розчином «Ектосан-плюс ${ }^{\mathrm{TM}} »$

Як видно з таблиці 1, із моменту застосування препарату «Ектосан-плюс ${ }^{\mathrm{TM}}$ » упродовж усього часу спостережень КВД обох концентрацій препарату (1:1000 і 1:750) мав значні розбіжності.

Зафіксовані відмінності показника були вірогідними відносно даних контрольної групи $(\mathrm{p}<0,001)$ i вказували, що робочий розчин у розведенні 1:750 суттєво збільшує термін захисту тварин від кровосисних комах. Після обробки корів першої групи достатній захисний ефект тривав тільки до 13:00 першого дня спостережень і становив 79,5\%. При цьому КВД у другій групі був вищим на 14,5\% $(\mathrm{p}<0,05)$.

Станом на 19:00 другої доби досліджень ефективність ветеринарного препарату «Ектосан-плюс ${ }^{\mathrm{TM}}$ » у першій групі знизилася до $70,7 \%$. Це було на $15,4 \%(\mathrm{p}<0,05)$ нижче за результат обробки тварин цим інсектицидом у розведенні 1:750 - КВД 81,6\%.

Оскільки ефективність «Ектосан-плюс ${ }^{\mathrm{TM}} »$ у розведенні 1:1000 виявилася недостатньою для захисту корів протягом світлового часу доби, подальші спостереження проводили за дією цього препарату в розведенні 1:750. У цій концентрації КВД інсектициду вище 75 \% був зафіксований терміном до 8:00 третьої доби експерименту після першої обробки тварин. Таким чином, ефективність препарату «Ектосан-плюс ${ }^{\mathrm{TM}} \gg$ була на достатньому рівні протягом 34 годин після першої обробки.

Повторне нанесення «Ектосан-плюс ${ }^{\mathrm{TM}} \gg$ на корів другої групи здійснили після вечірнього доїння на третю добу експерименту При цьому, КВД на вечір третьої доби зріс на 94,2 \% - до 69,9 \% порівняно з ранковим показником.

Подальші спостереження дозволили встановити, що впродовж 22 годин після другої обробки КВД «Ектосан-плюс ${ }^{\mathrm{TM}} 》$ у розведенні 1:750 досяг абсолютної $100 \%$ інсектицидної активності. I лише 3 18.00 шостої доби, тобто через 46 годин з моменту останньої обробки, КВД знизилась до 79,7 \%.

Таким чином, для інсектицидного захисту дійних корів може бути рекомендоване застосування «Ектосан-плюс ${ }^{\mathrm{TM}}$ у у розведенні 1:750 із нормою витрати $250 \mathrm{~cm}^{3}$ на тварину. У випадку помірної чи низької інтенсивності нападу зоофільних мух на корів достатньо однієї обробки раз на три доби, а за високої інтенсивності - один раз на дві доби. 
ВЕТЕРИНАРНА МЕДИЦИНА

1. Ефективність різних концентрацій «Ектосан-плюс ${ }^{m м » ~ щ о д о ~ з о о ф і л ь н и х ~ м у х ~(М \pm m) ~}$

\begin{tabular}{|c|c|c|c|c|c|c|}
\hline \multirow{3}{*}{\multicolumn{2}{|c|}{$\begin{array}{l}\text { Час проведення, до- } \\
\text { ба/годин }\end{array}$}} & \multirow{4}{*}{$\begin{array}{c}\begin{array}{c}\text { Контрольна } \\
\text { група, } \\
\text { екз./тв-ну, n=6 }\end{array} \\
18,71 \pm 0,59\end{array}$} & \multicolumn{4}{|c|}{ Дослідні групи, n=7 } \\
\hline & & & \multicolumn{2}{|c|}{ перша (розведення 1:1000) } & \multicolumn{2}{|c|}{ друга (розведення 1:750) } \\
\hline & & & екз./тв-ну & КВД. \% & екз./тв-ну & КВД. \% \\
\hline \multirow{6}{*}{ перша } & 9:00 & & 0 & 100 & 0 & 100 \\
\hline & $11: 00$ & $17,43 \pm 1,49$ & $3,86 \pm 0,80^{\circ}$ & 78,7 & $1,86 \pm 0,39^{\circ / *}$ & 89,8 \\
\hline & $13: 00$ & $21,43 \pm 1,56$ & $4,57 \pm 0,65^{\circ}$ & 79,5 & $2,00 \pm 0,30^{\circ / * *}$ & 91,0 \\
\hline & $15: 00$ & $18,14 \pm 1,3$ & $5,86 \pm 0,54^{\circ}$ & 69,0 & $2,14 \pm 0,26^{\circ / * * *}$ & 88,7 \\
\hline & $17: 00$ & $30,14 \pm 2,06$ & $9,43 \pm 1,37^{\circ}$ & 70,0 & $3,28 \pm 0,63^{\circ / * *}$ & 89,6 \\
\hline & 19:00 & $20,86 \pm 1,46$ & $10,00 \pm 0,61^{\circ}$ & 54,0 & $2,14 \pm 0,56^{\circ / * * *}$ & 90,1 \\
\hline \multirow{3}{*}{ друга } & $11: 00$ & $17,43 \pm 1,48$ & $7,28 \pm 0,63^{\circ}$ & 59,9 & $3,71 \pm 0,48^{\circ / * * *}$ & 79,6 \\
\hline & $17: 00$ & $17,57 \pm 1,56$ & $7,28 \pm 0,98^{\circ}$ & 60,2 & $3,28 \pm 0,52^{\circ / * *}$ & 82,1 \\
\hline & $19: 00$ & $29,00 \pm 2,74$ & $8,86 \pm 1,00^{\circ}$ & 70,7 & $5,57 \pm 0,95^{\circ / *}$ & 81,6 \\
\hline \multirow{2}{*}{ третя } & 8:00 & $1,71 \pm 0,33$ & - & - & $1,14 \pm 0,26$ & 36,0 \\
\hline & $18: 00$ & $26,00 \pm 1,52$ & - & - & $8,14 \pm 0,54^{\circ}$ & 69,9 \\
\hline четверта & $18: 00$ & $26,86 \pm 1,76$ & - & - & - & 100 \\
\hline \multirow{2}{*}{ п’ята } & 8:00 & $3,71 \pm 0,37$ & - & - & - & 100 \\
\hline & $18: 00$ & $23,00 \pm 4,11$ & - & - & $3,00 \pm 0,30^{\circ}$ & 87,4 \\
\hline шоста & $18: 00$ & $27,00 \pm 1,07$ & - & - & $5,71 \pm 0,37^{\circ}$ & 79,7 \\
\hline
\end{tabular}

Примітка: $1 .^{\circ}-\mathrm{p}<0,001$ порівняно $з$ даними контрольної групи; $2 .{ }^{*}-\mathrm{p}<0,05 ; 3 .{ }^{* *}-\mathrm{p}<0,01$; 4. *** $-\mathrm{p}<0,001$ порівняно $з$ даними дослідної групи.

Слід зазначити, що впродовж всього періоду експерименту зовнішніх проявів інтоксикації не було зафіксовано у жодної з дослідних тварин.

Підсумовуючи проведені дослідження, можна стверджувати, що водний розчин (1:750) лікарського засобу «Ектосан-плюс ${ }^{\mathrm{TM}}$ » 3 репелентним ефектом може бути рекомендований до широкого практичного застосування та захисту дійних корів від зоофільних мух в умовах тваринницьких приміщень. Це дасть змогу попередити небезпеку виникнення інфекційних та інвазійних хвороб, що поширюють мухи, як біологічні та резервуарні переносники багатьох збудників [2, 15].

\section{Висновки}

Ефективність (КВД) водного розчину (1:750) ветеринарного препарату «Ектосан-плюс ${ }^{\mathrm{TM}} »$ після першої обробки корів в умовах тваринницьких приміщень від нападу мух роду Stomoxys перевищує $80 \%$. Дія препарату за одноразового нанесення триває 34 години при витраті $250 \mathrm{~cm}^{3} /$ тварину. Щоденна обробка тварин зазначеним розчином збільшує тривалість інсектицидної дії «Ектосан-плюс ${ }^{\mathrm{TM}}$ » до трьох діб, що вказує на ймовірну накопичувальну дію засобу. Отже, для захисту великої рогатої худоби від нападу зоофільних мух доцільно застосовувати розчин «Ектосан-плюс ${ }^{\mathrm{TM}} »$ у розведенні 1:750 один раз на дві доби за умови інтенсивного нападу комах та однократно, з інтервалом три доби, за помірної чи низької активності мух.

Перспективи подальших досліджень. У подальших наших дослідженнях планується провести широке виробниче випробування серійної партії препарату «Ектосан-плюс ${ }^{\mathrm{TM}} 》$ щодо волосоїдів Bovicola bovis. Встановити вплив на молочну продуктивність інвазованих B. bovis корів лікувальних обробок цим засобом. 


\section{BETЕРИНАРНА МЕДИЦИНА}

References

1. Hutsul, T. A. (2011). Efektyvnist ta perspektyvy rozvytku molochnoho skotarstva v Ukraini. Visnyk Sums'kogo nacional'nogo agrarnogo universytetu, 1, 40-46 [In Ukrainian].

2. Domatskyi, V. N. (2018). Zaschita krupnogo rogatogo skota ot parazitov. Nauchnyiy almanah, 7 (1), 237-239. doi:10.17117/na.2018.07.01.237 [In Russian].

3. Kvichko, L. I., Abramov, V. E. \& Panfilova, M. N. (2011) Effektivnost preparata na osnove tsiflutrina protiv zoofilnyih muh. Teoriya i praktika parazitarnyih bolezney zhivotnyih, 12, 239-240 [In Russian].

4. Nychyk, A. V. (2009). Orhanizatsiino-ekonomichni osnovy veterynarnoho obsluhovuvannia silskohospodarskykh pidpryiemstv. Sumy: Sobor [In Ukrainian].

5. Pavlov, S. D. \& Pavlova, R. P. (1982) Metodicheskie rekomendatsii po izucheniyu insektitsidnyih preparatov. Moscow: VASHNIL [In Russian].

6. Pyatakova, S. A. (1998). Gotovyie lekarstvennyie formyi. Kharkov: Feniks [In Russian].

7. Tkachev, A. V. (2004). Piretroidnyie insektitsidyi - analogi prirodnyih zaschitnyih veschestv rasteniy. Sorosovskiy obrazovatelnyiy zhurnal, 2 (8), 56-63 [In Russian].

8. Chuieshov, V. I., Khokhlova, L. M., Liapunova, O. O., Saiko, O. V., Hladukh, Ye. V., Yehorov, I. A., Rybachuk, D. B., Pashniev, P. D. \& Bohuslavska, L. I. (2003). Tekhnolohiia likiv promyslovoho vyrobnytstva. Kharkiv: Zoloti storinky [In Ukrainian].

9. Allan, B. F., Keesing, F. \& Ostfeld, R. S. (2003). Effect of forest fragmentation on Lyme disease risk. Conservation Biology, 17 (1). 267-272. doi:10.1046/j.1523-1739.2003.01260.

10. Almazan, G. C., Castillo, S. S. \& Loredo, O. J. (2001). Dinamica poblacional de Haematobia irritans en un hato de bovinos de Soto la Marina, Tamaulipas, Mexico. Veterinaria-Mexico, 2 (32), 149-152.

11. Anziani, O. S., Zimmermann, G., Guglielmone, A. A., Forchieri, M. \& Volpogni, M. M. (2000). Evaluation of insecticide ear tags containing ethion for control of pyrethroid resistant Haematobia irritans (L.) on dairy cattle. Veterinary Parasitology, 1/2 (91), 147-151. doi:10.1016/S0304-4017(00)00254-5.

12. DeRouen, S. M. \& Foil, L. D. (2000). Efficacy of doramectin 0,5\% w/v pour-on for control of the horn fly, Haematobia irritans. Veterinary Parasitology, 4 (90), 327-331.

13. Felippe-Bauer, M. L., Cáceres, A., Santos da Silva, C., Valderrama-Bazan W., Gonzales-Perez, A. \& Costa, J. M. (2008). New records of Culicoides Latreille (Diptera: Ceratopogonidae) from Peruvian Amazonian Region. Biota Neotropica, 8 (2), 34-38. doi:10.1590/S1676-06032008000200002.

14. Katsuda, Y. (1999). Development of and future prospects for pyrethroid chemistry. Pesticide Science, 55, 775-782. doi:10.1002/(SICI)1096-9063(199908)55:8.

15. Kulkarni, P. D., Danayat, S. V., Potdar, P. M. \& Mujumdar, K. A. (1992). Control of lice infestation in dairy cattle with deltamethrin (Butox). Indian Veterinary Journal, 69 (12), 1129-1130.

16. Rachel, S. M., Roger, D. M., Marcia, R. H. \& Krishona, L. M. (2018). Effectiveness of Stable Fly Protectants on Adult Horses. Journal of Equine Veterinary Science, 69, 11-15. doi:10.1016/j.jevs.2018.06.002.

17. Sharge, L., Wu-Pong, S. \& Andrew, B. C. (2012). Applied Biopharmaceutics \& Pharmacokinetics : Sixth Edition. USA : The McGraw-Hill Companies.

18. Strycharz, J. P., Yoon, K. S. \& Clark, J. M. (2008). A new ivermectin formulation topically kills permethrin-resistant human head lice (Anoplura : Pediculidae). Journal of Medical Entomology, 45 (1), 7581. doi:10.1603/0022-2585(2008)45.

19. Stubbs, A. \& Drake, M. (2001). British Soldierflies and Their Allies: A Field Guide to the Larger British Brachycera. British Entomological \& Natural History Society.

20. Taylor, D. B., Moon, R. D. \& Mark, D. R. (2012). Economic impact of stable flies (Diptera: Muscidae) on dairy and beef cattle production. Journal of Medical Entomology, 49 (1), 198-209. doi:10.1603/me10050.

Бібліографічний опис для цитування:

Стаття надійшла до редакції 24.05.2019 р.

Шевченко А. М. Щодо контролю нападу зоофільних мух на корів в умовах тваринницьких приміщень. Вісник ПДАА. 2019. № 2. С. 232-237. 